\title{
Twin pregnancy a complicating journey for both mothers and babies: elaborate review
}

\author{
Pallavi Sitaram Shelke, Pradnya Nilesh Jagtap*
}

Department of Pharmacology Department, PDEA’s S.G.R.S. College of Pharmacy, Saswad, Maharashtra, India

Received: 18 January 2020

Revised: 04 March 2020

Accepted: 05 March 2020

\section{*Correspondence:}

Dr. Pradnya Nilesh Jagtap,

Email: pnj1511@gmail.com

Copyright: (c) the author(s), publisher and licensee Medip Academy. This is an open-access article distributed under the terms of the Creative Commons Attribution Non-Commercial License, which permits unrestricted non-commercial use, distribution, and reproduction in any medium, provided the original work is properly cited.

\begin{abstract}
Pregnancy, also known as gestation, is the time during which one or more offspring develops inside a woman. A multiple pregnancy involves more than one offspring, such as with twins. Pregnancy can occur by sexual intercourse or assisted reproductive technology. A pregnancy may end in a live birth, abortion, or miscarriage, though access to safe abortion care varies globally. Research shows that 10 percent to 15 percent of all singleton births may have started off as twins; often one is lost early in pregnancy in a phenomenon known as "vanishing twin syndrome." Multiple pregnancy occurs when two or more ova are fertilized to form dizygotic (non-identical) twins or a single fertilised egg divides to form monozygotic (identical) twins. In the U.S, about three in every 100 pregnant women give birth to twins or triplets, according to the Mayo Clinic in Rochester, Minn. And by many accounts, twin pregnancies are on the rise. This review provides a blessful information to understand what happening when expecting twins and also help to cope with pregnancy related complications and give twins the best start in life.
\end{abstract}

Keywords: Birth defects, Complications, Health concern, Risk factors, Twin or multiple gestation

\section{INTRODUCTION}

Twin or multiple births are much more common today than they were in the past. Pregnancy is a happy and joyous time for many women. It can also be a challenging time of life as the mother's body goes through numerous changes in order to create and support the development of a new life. ${ }^{1}$ A woman can be pregnant with twins or multiples either by chance (genetic factors) or due to some medical treatments. There is no sure-shot way of getting pregnant with twins. Multiple pregnancies, as the name suggests, is a pregnancy in which the mother carries more than one foetus in the uterus. ${ }^{2}$ The most common type of multi-fetal pregnancy is twins, where there are two babies developing simultaneously in the womb. Rarely, there are three or four foetuses developing in a single pregnancy. ${ }^{3}$

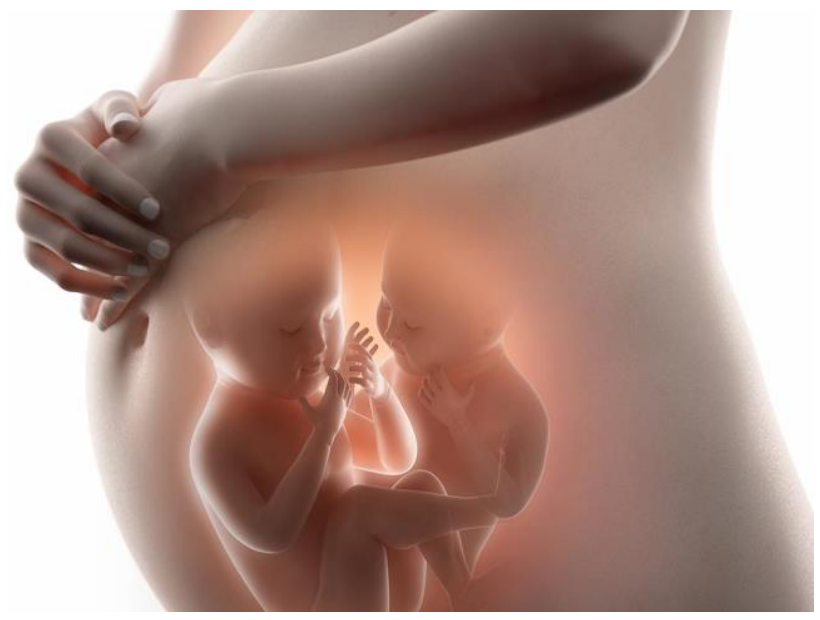

Figure 1: Twin pregnancy overview journey. ${ }^{4}$ 


\section{General odds of having twins}

The $21^{\text {st }}$-century statistics show that the possibility of having twins are $3 \%$, i.e. 3 in 100 among the general population. Figures also show that there is an increase of almost $61 \%$ from the early 1980s. A much recent update from the US National Center for Health Statistics says that the twin birth rate is 33.9 per 1000 live births. $^{5}$

\section{CLASSIFICATION}

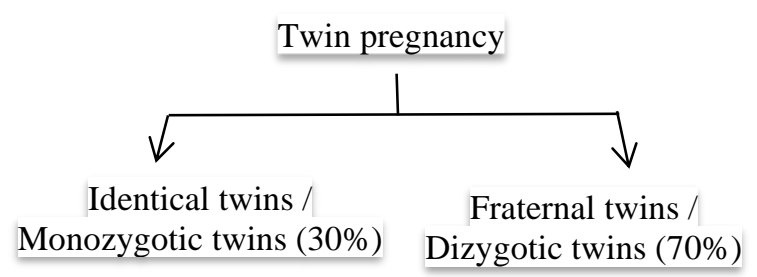

Figure 2: Classification of twin pregnancy.

\section{Identical twins/monozygotic twins}

Identical twins are also referred to as monozygotic twins or one-egg twins. They are the result of a single egg, fertilized by a single sperm cell. Very early in development, the egg divides, resulting in two individuals with the same DNA. Even though they may look identical, they have their own unique traits. This is due to various growth conditions in the womb. About 25 percent of all identical twins may be mirror twins. They are a subset of identical twins and are identical twins with opposite features. These mirrors are reflections of each other which means that the left side of one twin, matches the right side of the other twin. They may possess matching or almost matching fingerprints and share the same DNA. Organs and birthmarks can be placed on opposite sides of their bodies and one twin may be righthanded, whereas the other is left-handed. They result from a late split of the fertilized egg. ${ }^{6}$

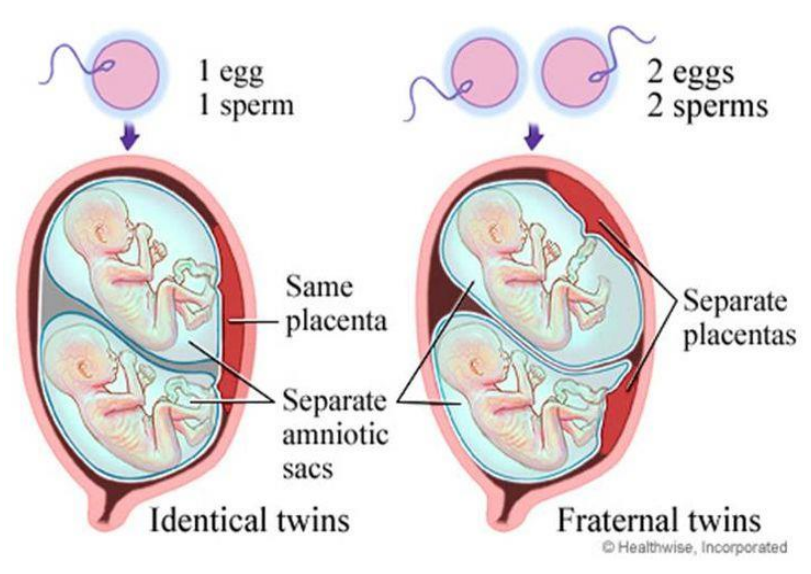

Figure 3: Main types of twin pregnancy. ${ }^{6}$

There are some patterns of identical twinning that are exceedingly rare: in extremely rare cases twins that stem from one egg have been born with opposite sexes. The probability of this is extremely small- multiples having different genders is universally accepted as a sound basis for a clinical determination, which multiples do not stem from one egg. ${ }^{7}$

\section{Fraternal twins/dizygotic twins}

Fraternal twins are also referred to as dizygotic twins, non-identical twins or two-egged twins. They develop from two different eggs; each is fertilized by separate sperm cells. They share approximately 50 percent of their genes, similar to any other siblings born at different times, who have the same biological mother and father. This means, that the chances of them looking alike are the same as the likelihood of any other siblings. They may look very much alike- or they may look very different.

Fraternal twins can be either gender or a combination of boy and girl. There are some patterns of twinning that are exceedingly rare. In rare cases, a woman's eggs are fertilized at different times with two or more acts of sexual intercourse. This is known as superfetation and occurs when a woman continues ovulating after becoming pregnant. ${ }^{8}$

There have also been instances of fraternal twins with different fathers. This occurs when a woman releases multiple eggs and has sexual relations with more than one partner. If an egg is fertilized by sperm from one man, and then another egg is fertilized by sperm from another man, the result is fraternal twins with different fathers. This phenomenon is termed heteropaternal superfecundation and these fraternal twins are genetically half-siblings and share approximately 25 percent of their DNA. ${ }^{8}$

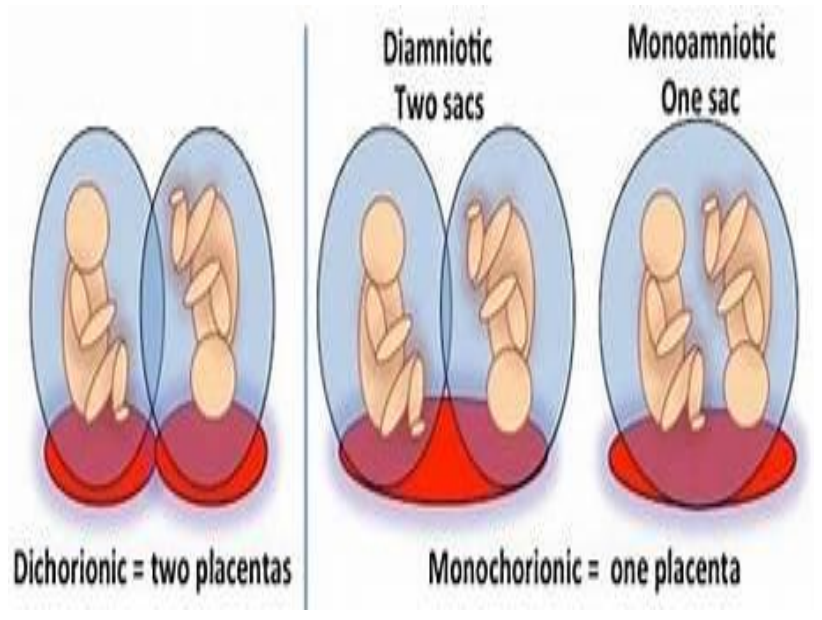

Figure 4: Determining chorionicity and amnionicity. ${ }^{9}$

\section{Conjoined twins}

Conjoined twins are also referred to as Siamese twins. Conjoined twins are identical twins whose bodies are 
joined together at birth. This occurs when the fertilized egg fails to separate completely because they split very late in development. Most conjoined twins are also mirror twins.

There is a type of conjoined twin that is sometimes referred to as parasitic twin. The condition is called Twin Reversed Arterial Perfusion (TRAP). Parasitic twins develop asymmetrically, with a smaller, less formed twin dependent on the stronger, larger twin. A variation of parasitic twinning is a fetus in fetu, where an abnormally formed mass of cells grows inside the body of its identical twin. It survives during pregnancy, and even occasionally after birth, by tapping directly into the blood supply of the host twin. ${ }^{10}$
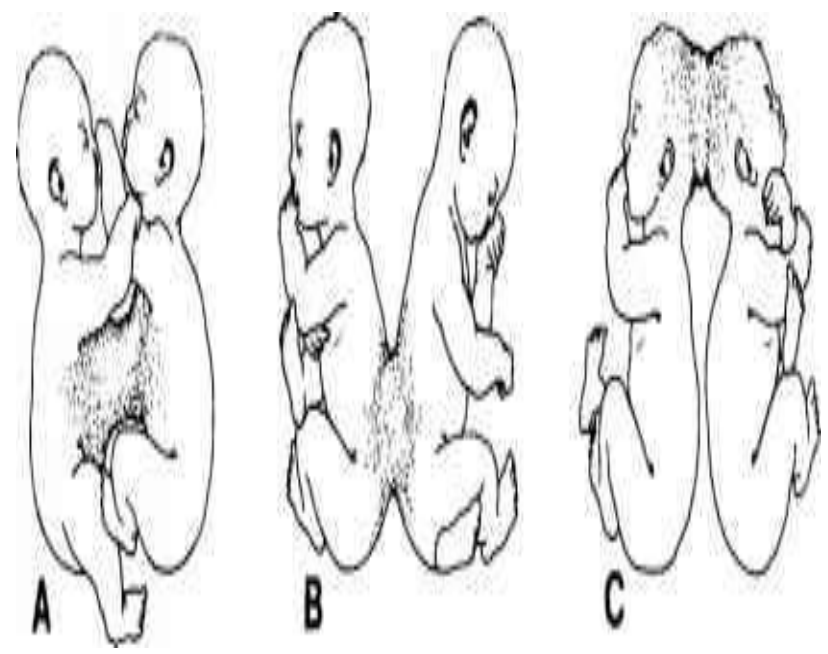

Figure 5: Conjoined twins. ${ }^{11}$

\section{Semi identical twins}

Semi identical twins are also referred to as polar body twins or half identical twins. Semi identical twins are types of twins, who share half their genes in common from the mother and the other half different from two separate sperm cells. This occurs when two sperm fertilize one egg, which then later splits. They share some features of identical twins and some features of fraternal twins. These twins will look very much alike but aren't a 100 percent DNA match. An embryo created this way doesn't usually survive, but a few cases are known. ${ }^{11}$

\section{Mixed chromosome twins}

Mixed chromosome twins are also referred to as chimeras. In human biology, a chimera is an organism with at least two genetically distinct types of cells- or, in other words, someone meant to be a twin. But while in the mother's womb, two fertilized eggs fuse, becoming one fetus that carries two distinct genetic codes- two separate strands of DNA. Some individuals have been identified to have more than one distinct red blood cell type and individuals have been born, who are both female and male. ${ }^{12}$

\section{FACTORS THAT DETERMINE THE CHANCES OF HAVING TWINS}

Identical twins could only happen by sheer chance. But certain factors might influence the chances of having fraternal twins. ${ }^{13-15}$

\section{Family history/heredity}

A history of multiple pregnancies in the family increases the chances of it repeating. ${ }^{13}$

\section{Ethnicity/race}

Women origin is also believed to have a strong influence on their chance of having twins. Historically, women belonging to certain ethnicities stand a higher chance of having multiple pregnancies. ${ }^{13}$

\section{Type of body (height/weight)}

Although strange, it is said that taller women are more likely than shorter ones to conceive with twins. Also, heavier women have higher chances than thinner women. A research study published by the American College of Obstetrics and Gynaecology states that the increasing rates of multiple births are due to increased rates of obesity. It is found that women with a body mass index (BMI) of 30 and above are more likely to produce twins. This holds for only fraternal twins. ${ }^{14,15}$

\section{Maternal age}

The chance of having twins or more babies may increase with advancing age. Women above 35 years produce more FSH (follicle-stimulating hormone) than younger women. ${ }^{16}$ This hormone allows the ovaries to release eggs for ovulation. The higher the hormone levels, the more the eggs released during ovulation are, thereby resulting in multiple fetuses.

\section{More pregnancies}

If women had multiple pregnancies before, there may be a high chance of producing twins. The probability of twins might also improve with the increasing number of pregnancies. ${ }^{17}$

\section{COMPLICATIONS IN TWIN OR MULTIPLE PREGNANCY}

\section{Risks to mother}

\section{Miscarriage}

Sometimes babies in a multiple pregnancy, do not survive long enough to complete the full term. A medical condition called 'vanishing twin syndrome' occurs when 
one of the two babies in a twin pregnancy fail to survive. $^{18}$

\section{Pre-eclampsia}

Pre-eclampsia is a condition that leads to hypertension and increased blood pressure in the mother. Chances of having preeclampsia are elevated in multifetal pregnancies and can lead to further complications that can even cause the detachment of the placenta. ${ }^{18}$

\section{Postpartum haemorrhage}

Due to the sheer size of the placenta and the uterus in a multifetal pregnancy, the chances of the mother experiencing a haemorrhage inside the uterus are high. ${ }^{19}$

\section{Anaemia}

In multifetal pregnancies the nutritional needs of the baby are increased twice or thrice more than a singleton pregnancy, thereby making the mother prone to anaemia. $^{18}$

\section{C-section}

The chances of having a C-section delivery are very high with a multiple pregnancy. ${ }^{19}$

\section{Risk to mother's life}

The maternal mortality rates with multiple pregnancies are comparatively higher than singleton pregnancies owing to a number of risk factors like anaemia, haemorrhage, pre-eclampsia, etc. ${ }^{19}$

\section{Risks to foetus}

\section{Premature babies}

Multiple birth babies are at a higher risk of being born prematurely owing to the space and nutritional constraints inside the uterus. Babies born before 28 weeks of pregnancy, have underdeveloped internal organs, leading to postnatal complications. These babies are usually given life support in the neonatal care units until considerable growth is achieved. ${ }^{18}$

\section{Congenital defects}

Multiple birth babies have a two times higher chance of having birth defects such as neural tube defects, cardiac defects and gastrointestinal defects, compared to single birth babies. ${ }^{17}$

\section{Twin-twin transfusion}

This is a condition in which monozygotic identical twins who share the placenta do not get an equal share of blood and nutrients. In some rare cases, the blood vessels form in such a way that one of the foetuses gets more blood compared to the other. This condition can lead to growth defects in the undernourished baby. ${ }^{19}$

\section{Intrauterine growth restrictions or IUGR}

These are very likely to occur with twins or more, due to the lack of space for the foetus to grow. In such cases, babies appear smaller and do not gain sufficient weight inside the womb. ${ }^{19}$

\section{DIAGNOSIS}

The diagnosis of twin pregnancies is possible during the initial stages of pregnancy itself with the help of the necessary technologies. Some of the techniques that doctors use to check for multifoetal pregnancy are: ${ }^{20,21}$

\section{HCG levels}

The hormone human chorionic gonadotrophin is generally elevated in a pregnant woman. These levels are comparatively higher for those carrying more than one foetus. Therefore, the level of HCG hormone in the blood is a clear indicator of multiple pregnancies.

\section{Ultrasound scan}

The regular ultrasound scan will give conclusive evidence on multiple pregnancies. A woman carrying more than one foetus can come to know of it as early as 20 weeks of her pregnancy, through a simple ultrasound scan.

\section{Blood test}

During pregnancy, the foetus secretes a protein called Alpha-fetoprotein (AFP) from its liver, which integrates into the bloodstream of the mother.

A measurement of the level of AFP is usually done during the $15^{\text {th }}$ and $17^{\text {th }}$ week of pregnancy. A higher level of AFP is one of the early signs of the woman carrying more than one foetus.

\section{PRECAUTIONS TO BE TAKEN IN CASE OF TWIN PREGNANCY}

When pregnant women diagnosed with twin pregnancies, some precautions that can be taken by her to avoid any associated complications. ${ }^{22-25}$

\section{Higher nutrient intake}

As the nutritional demands of the growing foetuses are double, a conscious increase in the consumption of nutrients can go a long way in reducing the risk of undernourishment both for babies and the mother. ${ }^{22}$ 


\section{Continued monitoring}

Women carrying more than one foetus are often advised to visit the doctor more frequently to carry out a continuous assessment of the health of the baby and the mother. Regular ultrasound scans are done to check for any kind of anomaly at every stage of the pregnancy. ${ }^{22}$

\section{Rest}

Multiple pregnancies of a higher order like triplets or quadruplets warrant a lot of bed rest as these pregnancies are associated with a lot of complications. Depending on the risk factors, doctors even advice women with twin pregnancies to take adequate bed rest. ${ }^{23}$

\section{Stitching of the cervix}

Many women who carry multiple babies have increased chances of cervical incompetence. In order to avoid the opening up of the cervix before the completion of the full term, doctors stitch the mouth of the cervix in a process termed as cervical cerclage. ${ }^{24}$

\section{Medications}

Doctors often prescribe nutritional supplements in the form of medicines and other hormones like corticosteroids for ensuring a safe delivery. ${ }^{25}$

Table 1: The required weight gain during pregnancy as per the body mass index of the expecting mother. ${ }^{26}$

\begin{tabular}{|lll|}
$\begin{array}{l}\text { Pre- pregnancy } \\
\text { weight }\end{array}$ & $\begin{array}{l}\text { Body mass } \\
\text { index }\end{array}$ & $\begin{array}{l}\text { Recommended } \\
\text { weight gain (pounds) }\end{array}$ \\
\hline Underweight & Less than 18.5 & $28-40$ \\
\hline Normal weight & $18.5-24.9$ & $25-35$ \\
\hline Overweight & $25-29.9$ & $15-25$ \\
\hline Obese & 30 and greater & $11-20$ \\
\hline
\end{tabular}

\section{NUTRITIONAL REQUIREMENTS OF WOMEN EXPECTING TWINS}

If women is pregnant with twins, her calorie intake in the first trimester should be around 300; 680 calories in the second trimester, and 900 extra calories in the third trimester of her pregnancy. ${ }^{27}$

Table 2: List of nutrition and it's source. ${ }^{28}$

\begin{tabular}{|c|c|c|c|}
\hline $\begin{array}{l}\text { Nutrition } \\
\text { requirement }\end{array}$ & Intake (per day) & Food source & Use \\
\hline Protein & $100-175$ grams & $\begin{array}{l}\text { Lean meats (beef, turkey, } \\
\text { chicken, pork), nuts, } \\
\text { yoghurt, milk, cottage, } \\
\text { cheese, tofu }\end{array}$ & $\begin{array}{l}\text { Protein is a vital component for the creation of } \\
\text { human cells and thus should be a part of daily diet. }\end{array}$ \\
\hline Iron & $30 \mathrm{mg}$ & $\begin{array}{l}\text { Red meat, seafood, nuts, } \\
\text { fortified cereal }\end{array}$ & $\begin{array}{l}\text { Iron helps in reducing the risk of anaemia, } \\
\text { hypertension, and preterm delivery. }\end{array}$ \\
\hline Calcium & $1,500-2500 \mathrm{mg}$ & $\begin{array}{l}\text { Milk, yoghurt, spinach, } \\
\text { kale, okra }\end{array}$ & $\begin{array}{l}\text { Calcium is very important for the formation of strong } \\
\text { teeth and bones. }\end{array}$ \\
\hline Carbohydrates & $300-400$ grams & $\begin{array}{l}\text { Bread, potatoes, pasta, } \\
\text { rice, cereal }\end{array}$ & $\begin{array}{l}\text { Carbohydrates are broken down into simple sugars } \\
\text { like glucose, which gives energy to growing baby. }\end{array}$ \\
\hline Folic acid & $1000 \mathrm{mg}$ & $\begin{array}{l}\text { Spinach, asparagus, } \\
\text { oranges, grapefruit }\end{array}$ & $\begin{array}{l}\text { Taking folic acid during pregnancy can prevent baby } \\
\text { from developing birth defects of the spinal cord and } \\
\text { brain. It is important that take folic acid for a healthy } \\
\text { pregnancy. }\end{array}$ \\
\hline $\begin{array}{l}\text { Salt and } \\
\text { healthy fats }\end{array}$ & $\begin{array}{l}\text { Salt: } 3.8-5 \text { gram } \\
\text { Healthy fats: } 120 \\
\text { grams }\end{array}$ & $\begin{array}{l}\text { Salt, almonds, walnuts, } \\
\text { avocado, olive oil, } \\
\text { sunflower oil, corn oil, } \\
\text { flax seeds and soybeans }\end{array}$ & $\begin{array}{l}\text { Salt is essentially sodium which keeps everything in } \\
\text { balance. Table salt generally contains iodine which is } \\
\text { extremely important for the proper development of } \\
\text { baby's brain and nervous system. Healthy fats also } \\
\text { facilitate proper brain growth and eye development. }\end{array}$ \\
\hline $\begin{array}{l}\text { Vitamin } \\
\text { suppliments }\end{array}$ & 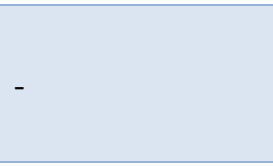 & $\begin{array}{l}\text { Iron, iodine, folic acid, } \\
\text { vitamin } \mathrm{D} \text {, vitamin } \mathrm{C} \text { etc. }\end{array}$ & $\begin{array}{l}\text { Most women get nutrients from a healthy and } \\
\text { balanced meal. However, if pregnant women do not } \\
\text { have a good appetite, the doctor may prescribe some } \\
\text { vitamin supplements. }\end{array}$ \\
\hline Water & $\begin{array}{l}\text { Need to drink } \\
\text { around } 10 \text { cups of } \\
\text { water everyday }\end{array}$ & - & $\begin{array}{l}\text { Drinking a lot of water throughout the day will } \\
\text { prevent dehydration during pregnancy. }\end{array}$ \\
\hline
\end{tabular}

\section{FERTILITY TREATMENTS TO HAVE TWINS}

\section{In vitro fertilization}

Women who undergo in vitro fertilization (IVF) may have fair chances of giving birth to more than one baby.
However, it mainly depends on the number of embryos placed in the uterus. To increase the odds of twin conception, the healthcare experts might place more than one embryo into the womb. If both are implanted and developed successfully, it is likely to result in twin pregnancy. ${ }^{29}$ 


\section{Intrauterine insemination}

In this procedure, the sperms are injected into the uterus using a syringe. However, intrauterine insemination (IUI) alone will not increase the chances of having multiples. Women who undergo this treatment may have to take fertility drugs to increase the likelihood..$^{30}$

\section{Folic acid supplements}

One Australian study showed that a woman's chances of producing twins increases by taking folic acid before pregnancy. ${ }^{31}$ Another study reports that women undergoing IVF treatments, along with excess intake of folate, have an increased chance of birthing twins. ${ }^{32}$

However, studies supporting the theory that folic acid consumption may increase the chances of twin conception are limited. Also, there are no large-scale studies to support this claim.

\section{Gonadotropin}

These medications might improve the chances of having twin babies as they enhance the overall health of eggs and their maturity. Gonadotropins are likely to stimulate the release of more than one egg at a time. ${ }^{33}$

\section{Clomid (Clomiphene citrate)}

There is around $10 \%$ chance of producing twins with Clomiphene or Clomiphene citrate. Women who already have higher probability or twin births may also improve their chances further with Clomid. The pill may be taken before trying assisted reproductive treatments like in vitro, to promote egg production. It might also help treat hormonal imbalances in men, which may affect the quality and quantity of sperm, and their motility. ${ }^{34}$

\section{Fertility herbs for twins ${ }^{35}$}

Evening primrose oil is believed to promote healthy cervical mucus that might allow the sperm to survive within the ovary for a longer time. Liquorice is said to control hormonal levels of estrogen and testosterone, and might support conception.

Flaxseed oil is likely to boost fertility and might increase chances of twin conception.

Sweet cassava is also said to increase the chances of twins due to its hyper-ovulation properties. Black cohosh is not known to increase the chance of twin conception, but it is believed to increase the fertility rate.

Vitex (chaste tree berry) might regulate hormonal levels, promote ovulatory function, and may prevent ovarian cysts, all of which are thought to be favorable for twin conception. Maca root is also believed to improve overall fertility that might improve the chances of having twins.

\section{MODE OF DELIVERY}

The position of the baby inside the womb, vertex or breech, majorly decides the mode of delivery. The baby is delivered either vaginally or through C-section, depending on factors like the position of the foetus, health of the mother and the babies, stage of pregnancy, etc. ${ }^{36}$

\section{Vaginal delivery}

Usually, a vaginal delivery is done only when there are no complications. In the case of twins, if both babies are in a head down (vertex) position, a normal vaginal delivery is possible. However, a normal vaginal delivery also is performed in an operation theatre for catering to any kind of emergency. ${ }^{37}$

\section{Operative delivery}

If the foetuses are delivered pre-term, they are usually delivered through $\mathrm{C}$-section to avoid causing any risk to mother and the baby. In the case where one or both the babies are in breech position, a caesarean is preferred to minimise the risk of any complications. For mothers carrying three or more foetuses, a C-section is always the choice of delivery. ${ }^{38}$

\section{FUTURE COMPLICATIONS}

Some common complications with twin babies are, breastfeeding of two or more babies at a time can be a very challenging task for the new mother. Lactation and feeding are very much possible with multiple babies and a lactation consultant can be very helpful in establishing a feeding routine. ${ }^{39}$ Women who have delivered twins or triplets stand a higher chance of experiencing postpartum depression. Having supportive family and friends can go a long way in staying positive and happy. ${ }^{40}$ Pre-mature babies may have some developmental complications in future. Regular postnatal checkups are required to ensure the well-being of the babies, especially if they are born with some birth defects. ${ }^{41}$

\section{BREASTFEEDING BOOST: NURSING MAY HELP MOTHERS IMPROVE HEART HEALTH}

Studies have long touted the benefits of breastfeeding for infants, including stronger immune systems and lower risk for asthma, obesity and Type 2 diabetes. But babies aren't the only ones benefiting: Nursing also appears to provide health benefits for moms. A 2017 study published in the Journal of the American Heart Association found nursing may help mothers lower their risk of heart attack and stroke long after giving birth. The study didn't explain the reason behind the link, but 
researchers noted that breastfeeding helps women lose pregnancy-related weight, including fat reserves that help fuel fetal growth. This process may help "reset" the body's metabolism after giving birth. ${ }^{42}$

\section{OBSTETRIC MANAGEMENT ON FETAL DEATH OF A TWIN}

Again, the nature of the placentation determines precise management. In all circumstances consideration should be given to the use of corticosteroids to promote fetal lung maturity and magnesium sulphate for neuroprotection. A neonatal paediatric consultation should be arranged and close discussion between the parents, obstetrician and paediatrician over subsequent weeks is essential. ${ }^{43}$

If the live twin is leading, well grown and is in a cephalic presentation, then vaginal delivery may be considered. If the live twin is malpresenting or is growth restricted, or if the dead twin is leading, caesarean section is preferred. Many parents prefer caesarean section regardless of these considerations and this obviously needs to be discussed, taking into account the whole circumstances of the couple. $^{43}$

The development of a coagulopathy if a dead fetus is retained for more than four weeks is remarkably uncommon if the co-twin remains alive. Nevertheless, consideration should be given to perform weekly fibrinogen levels with a platelet count and a partial thromboplastin time after four weeks of confirmed fetal death. A full coagulation screen should be performed before regional analgesia or delivery. ${ }^{44}$

The loss of a twin at any stage of pregnancy is devastating for parents. The psychological issues related to grieving for the lost twin while preparing for the birth of the surviving twin may be profound. The thought of still carrying the retained dead twin and the uncertainty regarding long-term outcome compound the stress of losing a twin. Extensive counselling is often required. ${ }^{44}$

\section{Updated guidance for the management of twin and multiple pregnancies from the National Institute for Health and Care Excellence}

In September 2019, NICE published updated guidance on the management of multiple pregnancy (NG 137). Many of the previous recommendations for care are upheld but there have been important changes: increased frequency of combined ultrasound/specialist antenatal care appointments for pregnancies containing a monochorionic placenta (twins and triplets), increased frequency of ultrasound monitoring in all triplet pregnancies, changes in the definition of selective growth restriction and its subsequent referral pathways, the introduction of some monitoring for twin (or triplet) anemia polycythemia sequence in monochorionic pregnancies (albeit in complex pregnancies or at an advanced stage), and a recommended timing of birth for any pregnancy with monoamniotic fetuses. New recommendations have been made for mode of delivery, fetal monitoring in labor, maternal analgesia, and the prevention of postpartum hemorrhage. The absence of any recommendation relating to the prevention of preterm birth is notable. The basis and implications of the updates that may improve perinatal outcomes. $^{45}$

\section{DISCUSSION}

Twin pregnancy is the simultaneous development of two embryos in the uterus. The present data have witnessed a sharp rise in the incidence of twin and higher order gestations because of the availability and widespread use of ovulation inducing drugs, and the progress and developments in assisted reproductive technology. Twin pregnancy is associated with a high risk of maternal and neonatal complications. Common obstetric complications such as anemia, preeclampsia, antepartum haemorrhage, polyhydramnios, preterm labour and postpartum haemorrhage occur six times more in twin pregnancy than in singletons.

\section{CONCLUSION}

A twin pregnancy is a double blessing, but it can also come with risks for both the mothers and babies life. In this elaborate study it is observed that such mentioned complications double up in the event of a twin pregnancy. Early diagnosis of twin pregnancy, regular antenatal visits, identification of complications and planned delivery will help in decreasing maternal morbidity and mortality. This review provides most precious and blessing information for healthy twin pregnancy and to avoid the risk complications for both mothers and babies. Having twins is definitely a double dose of joy, but parents of twins will need to accept the challenging task to give their twins the best start in life.

Funding: No funding sources

Conflict of interest: None declared

Ethical approval: Not required

\section{REFERENCES}

1. Khalil A, Rodgers M, Baschat A, Bhide A, Gratacos E, Hecher K, et al. ISUOG Practice Guidelines: role of ultrasound in twin pregnancy. Ultrasound Obstet Gynecol. 2016;47(2):247-63.

2. Martin J, Hamilton B, Osterman M, Curtin S, Matthews T. Births: final data for 2013. Nat Vital Stat Rep. 2015;64:1-65.

3. Hamilton BE, Martin JA, Osterman MJK, Rossen LM. Births: Provisional data for 2018. Vital Statistics Rapid Release; no 7. Hyattsville, MD: National Center for Health Statistics. May 2019. Available at: https://www.cdc.gov/nchs/data/vsrr/vsrr-007-508. Accessed 4 Jan 2020. 
4. Twin Pregnancy Overview. Available at: https://fthmb.tqn.com/sWiW218z7qgi2Nr4hnATovY qMk=/768x0/filters:no_upscale()/GettyImages107702521-56a772b55f9b58b7d0ea99ff.jpg.

Accessed 6 January 2020.

5. Martin JA, Hamilton BE, Osterman MJK, Driscoll AK, Drake P. Births: final data for 2017; National Vital Statistics Reports; CDC/National Center for Health Statistics. National Vital Statistics Reports 2018;67(8):1-12.

6. Twin Pregnancy Types: Healthwise Medical Information on eMedicine Health. Available at: https://mediacacheak0.pinimg.com/736x/95/e7/22/95 e722aa355ef3b0a2f74ddc9dbc5565.jpg. Accessed 8 January 2020.

7. Frequently asked question. Pregnancy FAQ188. Multiple pregnancy. American College of Obstetricians and Gynecologists, 2019. Available at: https://www.acog.org/Patients/FAQs/Multiple-Pregnancy. Accessed 9 Jan 2020.

8. Gabbe S, Niebyl J, Simpson J, Landon M, Galan H, Jauniaux E, et al. Multiple gestations. In: Obstetrics: normal and problem pregnancies. 7th ed. Philadelphia, Pa.: Saunders Elsevier; 2017: 319-347.

9. Types of twin pregnancies images. Available at: https://www.hopkinsmedicine.org/gynecology_obstet rics/specialty_areas/fetal_therapy/_images/types-oftwin-pregnancy.jpg. Accessed 3 Jan 2020.

10. Washington DC. Multiples: When it's twins, triplets, or more. In: Your pregnancy and childbirth month to month. American College of Obstetricians and Gynecologists; 6th ed. 2015.

11. Conjugated twins images. Available at: http://austincoppock.com/wp-content/uploads/ 2012/04/ConjoinedTwinsGEMINI.jpg. Accessed 1 Jan 2020.

12. Hayes EJ. Multifetal gestations: twin, triplet, and higher-order multifetal pregnancies. Practice Bulletin No. 169. American College of Obstetricians and Gynecologists. Obstet Gynecol. 2016;128(4):131-46.

13. Washington DC. Twins, triplets, and other multiples; Office on Women's Health; U.S. Department of Health and Human Services, 2019. Available at: https://www.womenshealth.gov/pregnancy/yourepregnant-now-what/twins-triplets-and-othermultiples . Accessed 8 Jan 2020.

14. Reddy UM, Branum AM, Klebanoff MA. Relationship of maternal body mass index and height to twinning. Obstet Gynecol. 2005;105(3):593-7.

15. Droge L, Zeisler H, Schlembach D, Stepan H, Küssel L, Henrich W, et al. Maternal serum sFlt-1/PlGF ratio in twin pregnancies with and without preeclampsia in comparison with singleton pregnancies. Ultrasound Obstetr Gynecol. 2015;45:286-93.

16. Barua S, Kuizon S, Junaid MA. Folic acid supplementation in pregnancy and implications in health and disease. J Biomed Sci. 2014;21(1):77.

17. Dubey S, Mehra R, Goel P, Rani J, Satodiya M. Maternal complications in twin pregnancy; recent trends: a study at a tertiary care referral institute in
Northern India. Int $\mathbf{J}$ Reprod Contracept Obstet Gynecol. 2018;7(9):3753-7.

18. Tomar SP, Kushwah SS, Kushwah AP. Association of sociodemographic factors with multiple births and birth outcomes in comparison to single births among deliveries conducted at a tertiary hospital in Rewa, Madhya Pradesh. Int J Students Res. 2014;1;4(1):8.

19. Fuchs KM, Dalton ME. Monochorionic monoamniotic twin gestations. Obstet Imag Fetal Diagn Care. 2018;159(2):642-45.

20. Chasen ST, Chervenak FA. Twin pregnancy: Prenatal issues. UpToDate. 2017:1-45.

21. Ishii K. Prenatal diagnosis and management of monoamniotic twins. Curr Opin Obstet Gynecol. 2015;27(2):159-64.

22. Dodd JM, Dowswell T, Crowther CA. Specialised antenatal clinics for women with a multiple pregnancy for improving maternal and infant outcomes. Cochrane Database Syst Rev. 2015;7(4): 611-8.

23. Simpson LL. What you need to know when managing twins: 10 key facts. Obstet Gynecol Clin North Am. 2015;42(2):225-39.

24. Multiple pregnancy: antenatal care for twin and triplet pregnancies. NICE Clinical Guideline; 2011. Available at: https://www.nice.org.uk/ guidance/CG129. Accessed 3 Jan 2020.

25. Moayyeri A, Hammond CJ, Hart DJ, Spector TD. The UK Adult Twin Registry (TwinsUK Resource). Twin Res Hum Genet. 2013;16(1):144-9.

26. Rasmussen KM, Abrams B, Bodnar LM, Butte NF, Catalano PM, Siega-Riz AM. Recommendations for weight gain during pregnancy in the context of the obesity epidemic. Obstet Gynecol. 2010;116(5):1191-5.

27. American College of Obstetricians and Gynecologists, Society for Maternal-Fetal Medicine. ACOG Practice Bulletin No. 144: Multifetal gestations: twin, triplet, and higher-order multifetal pregnancies. Obstet Gynecol. 2014;123(5):1118.

28. Robinson S, Baird J, Godfrey KM. Eating for two? The unresolved question of optimal diet in pregnancy. Am J Clin Nutr. 2014;100:1220-6.

29. ACOG Committee on Obstetric Practice. ACOG Committee Opinion No. 495: Vitamin D: Screening and supplementation during pregnancy. Obstet Gynecol. 2011;118:197-8.

30. Roberts D, Neilson JP, Kilby MD, Gates S. Interventions for the treatment of Twin- Twin transfusion syndrome. Cochrane Database Syst Rev. 2014;3(1):3-18.

31. Persson PH, Grennert L. Diagnosis and treatment of twin pregnancy. Acta Geneticae Medicae et Gemellologiae. 1999;28(04):311-7.

32. Chandracharya PL, Alva R, Hosapatna M, Konuri A, Kumar A. Role of folic acid supplementation and/or its absence during pregnancy on implantation of embryos-An experimental study of Wistar rats. J Anatom Soc India. 2018;67(1):80-5. 
33. Thaler CJ. Folate metabolism and human reproduction. Geburtshilfe und Frauenheilkunde. 2014;74(09):845-51.

34. Jarde A, Lutsiv O, Park C, Barrett J, Beyene J, Saito $\mathrm{S}$, et al. Preterm birth prevention in twin pregnancies with progesterone, pessary or cerclage: a systematic review and meta-analysis. BJOG. 2017;124(3):116373.

35. Tamura H, Kishi H, Kitade M, Asai-Sato M, Tanaka A, Murakami T, et al. Clinical outcomes of infertility treatment for women with adenomyosis in Japan. Reprod Med Biol. 2017;16(3):276-82.

36. Lans C, Taylor-Swanson L, Westfall R. Herbal fertility treatments used in North America from colonial times to 1900 , and their potential for improving the success rate of assisted reproductive technology. Reprod Biomed Soc Online. 2018; 5(1):60-81.

37. Christopher D, Robinson BK, Peaceman AM. An evidence-based approach to determining route of delivery for twin gestations. Rev Obstet Gynecol. 2011;3(4):109-16.

38. Barrett JF, Hannah ME, Hutton EK, Willan AR, Allen AC, Armson BA, et al. A Randomized Trial of Planned Cesarean or vaginal delivery for twin pregnancy. N Engl J Med. 2013;369(14):1295-305.

39. Saving Lives Improving Mothers' Care: lessons learned to inform maternity care from the UK and Ireland Confidential Enquiries into Maternal Deaths and Morbidity 2009-13; MBRRACE-UK, 2015. Available at: https://www.npeu.ox.ac.uk/ downloads/ files/mbrrace-uk/reports/MBRRACE-UK\%20Maternal\%20Report\%202015.pdf. Accessed 5 January 2020 .
40. Santana DS, Cecatti JG, Surita FG, Silveira C, Costa ML, Souza JP, et al. Twin pregnancy and severe maternal outcomes: the World Health Organization multicountry survey on maternal and newborn health. Obstetr Gynecol. 2016;127(4):631-41.

41. Nandmer GK, Kanhere AV. Study of obstetric and fetal outcome of twin pregnancy in a tertiary care centre. Int J Reprod Contracept Obstetr Gynecol. 2017;4(6):1789-92.

42. Breastfeeding boost: Nursing may help mothers improve heart health, 2019. Available at: www.heart.org/en/news/2019/01/10/breastfeeding. Accessed 15 Jan 2020.

43. Umstad MP. Obstetric Management Update: Fetal Death of a Twin. O \& G Magazine. 2019;14(1):25460.

44. Chien P. The perinatal burden of preterm delivery and twin pregnancy. Int $\mathrm{J}$ Obstet Gynaecol. 2019;126(5):549-50.

45. Gibson JL, Castleman JS, Meher S, Kilby MD. Updated guidance for the management of twin and triplet pregnancies from the National Institute for Health and Care Excellence guidance, UK: What's new that may improve perinatal outcomes?. Acta Obstet Gynecol Scand. 2020 ;99(2):147-52.

Cite this article as: Shelke PS, Jagtap PN. Twin pregnancy a complicating journey for both mothers and babies: elaborate review. Int J Basic Clin Pharmacol 2020;9:674-82. 